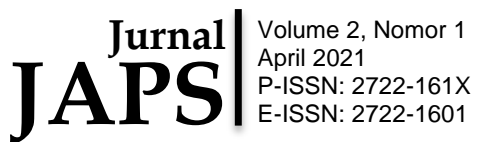

DOI: $10.24014 /$ jdr.v30i2.0000

\section{Komunikasi Pemerintah Pusat Dan Pemerintah Daerah: Kasus Dinamika Pelaksanaan Local Lockdown Dalam Mencegah Penyebaran COVID-19}

\author{
Ardi Putra', Tito Handoko ${ }^{2}$ \\ ${ }^{1}$ Program Studi Ilmu Pemerintahan, Fakultas Ilmu Sosial dan Ilmu Politik. \\ Universitas Maritim Raja Ali Haji. \\ ${ }^{2}$ Program Studi Ilmu Pemerintahan, Fakultas Ilmu Sosial dan Ilmu Politik, \\ Universitas Riau \\ Email : $\underline{\text { ardi.putar@umrah.ac.id , tito.handoko@lecturer.unri.aci.id }}$
}

\section{Kata kunci}

Keywords

Komunikasi

Pemerintahan,

Kebijakan, Local

Locakdown, Covid'19

\section{Abstrak}

Dalam pelaksanaan local lockdown harus terjalin hubungan komunikasi yang baik antara Pemerintah Pusat dan Pemerintah Daerah dalam mencegah penyebaran covid-19 ditingkat lokal. (Sedarmayanti, 2018) menjelaskan setidaknya ada beberapa unsur dalam komunikasi pemerintahan antaranya adalah; Komunikator, Pesan, Media, Komunikan dan Feedback. Berdasarkan latar belakang diatas adapun rumusan masalah yang akan penulis angkat adalah bagaimana pola komunikasi pemerintah pusat dan pemerintaha daerah: kasus dinamika pelaksanaan local lockdown dalam mencegah penyebaran COVID-19, tujuan dari penulisan artikel ini adalah untuk mengetahui komunikasi pemerintah pusat dan pemerintahan daerah: kasus dinamika pelaksanaan local lockdown dalam mencegah penyebaran covid'19. Penelitian ini menggunakan metode penelitian kualitatif dengan jenis penelitian yaitu studi literature pengambilan data melalui dokumentasi, buku, jurnal dan media massa. Hasil dari penelitian ini adalah: komunikasi Pemerintah Pusat dan Pemerintah Daerah tidak berjalan secara harmonis, ditandai dengan adanya beberapa daerah yang menerapkan local lockdown diantaranya adalah Kota Tegal, Kota Tasikmalaya dan Provinsi Papua.

\footnotetext{
Abstract

In implementing the local lockdown, a good communication relationship must be established between the Central Government and Regional Governments in preventing the spread of Covid-19 at the local level. (Sedarmayanti, 2018) explained that at least there are several elements in government communication, including; Communicators, Messages, Media, Communicate and Feedback. Based on the background above, the problem formulation that the writer will raise is how the communication patterns of the central government and local governments: the case of the dynamics of
} 


\begin{abstract}
implementing local lockdowns in preventing the spread of COVID19, the purpose of writing this article is to find out the communication between the central government and local governments: the case of dynamics. implementation of a local lockdown to prevent the spread of covid'19. This research uses qualitative research methods with this type of research, namely literature study data collection through documentation, books, journals, and mass media. The results of this study are: the communication between the Central Government and the Regional Government does not run harmoniously, indicated by the presence of several regions implementing local lockdowns, including the City of Tegal, the City of Tasikmalaya, and the Province of Papua.
\end{abstract}

\title{
Pendahuluan
}

Konstitusi Negara Kesatuan Republik Indonesia (NKRI) yaitu Undang-Undang Dasar 1945 menjelaskan tentang tugas dan fungsi pemerintah (BAB XIV) bahwa Negara berkewajiban dan bertanggung jawab atas pertahanan dan keamanan negara, penyediakan pelayanan kesehatan dan fasilitas umum yang layak, jaminan terhadap sistem jaminan sosial bagi seluruh rakyat dan pemberdayaan kepada masyarakat yang lemah dan tidak mampu, dan menjamin perekonomian nasional. Dalam konteks penyelenggaraan kewenangan pemerintahan pusat mengacu pada ketentuan UndangUndang Dasar 1945, sebagai landasan konstitusi Negara Kesatuan Republik Indonesia. Indonesia adalah Negara kesatuan yang dipimpin oleh Presiden sebagai Kepala Pemerintahan, Indonesia terdiri dari beberapa daerah otonom berdasarkan UndangUndang Dasar 1945 Pasal 18, yang setiap daerah dipimpin oleh Kepala Daerah (Gubernur, Bupati, Walikota) yang dipilih berdasarkan asas demokrasi.

Dalam menjalankan kewenangan antara Pemerintah Pusat dan Pemerintah Daerah harus diatur sedemikian rupa agar terjadi hubungan yang harmonis. Berdasarkan studi (Abdul Rauf Alauddin Said, 2015) menjelaskan bahwa hubungan wewenang antara Pemerintah Pusat dan Pemerintah Daerah harus diatur dalam Peratuarn Perundangundangan, sehingga hubungan tersebut mendapat legitimasi dan pengaturan bersama. Adanya asas desentralisasi merupakan bentuk dari hubungan kewenangan antara Pemerintah Pusat dan Pemerintah Daerah. Salah satu bentuk dari adanya hubungan kewenangan dari Pemerintah Pusat dan Pemerintah Daerah adanya Undang-Undang Nomor 23 Tahun 2014 tentang Pemerintah Daerah.

Undang-undang 23 Tahun 2014 mengatur tentang pembagian tuags antara Pemerintah Pusat dan Pemerintah Daerah. Dalam studi lain (Wirazilmustan, Rahmat, 2018) menjelaskan bahwa hubungan kewenangan antara Pemerintah Pusat dan Pemerintah Daerah merupakan bentuk dari penyerahan wewenang dari Pemerintah Pusat kepada Pemerintah Daerah, dimana meskipun Undang-Undang 23 Tahun 2014 mengatur tentang kewenangan Pemerintah Daerah namun wewenang tersebut merupakan delegasi dari Pemerintah Pusat kepada Pemerintah Daerah. Undang-Undang Nomor 23 Tahun 2014 telah mengatur pembagian urusan Pemerintahan, baik itu secara 
Absolut, Konkuren dan Umum. Berdasarkan Pasal 10 tentang urusan Pemerintahan absolut bahwa urusan pemerintahan absolut dilaksanakan oleh Pemerintahan Pusat secara langsung yang terdiri dari Politik Luar Negeri, Pertahanan, Keamanan, Yustisi, Moneter dan fiskal nasional dan Agama.

Kemudian urusan konkuren yang mejadi kewenangan Pemerintahan Daerah yang terdiri atas urusan pemerintahan wajib pelayanan dasar, urusan wajib/Non-pelayanan dasar dan urusan pemerintahan pilihan yang diatur dalam pasal 11 diantaranya adalah Pendidikan, Kesehatan, Pekerjaan umum dan penataan ruang, Perumahan rakyat dan Kawasan Permukiman, Ketentraman, ketertiban umum, dan pelindungan masyarakat dan Sosial

Berdasarkan ke-6 unsur urusan diatas merupakan kewajiban dari Pemerintahan Daerah dalam menjalankan wewenang, tugas dan fungsi sebagai penyelenggara Pemerintah Daerah yang terdiri dari Provinsi, Kabupaten/Kota yang di pimpin oleh Kepala Daera yaitu Gubernur, Bupati /Walikota. Dalam studi (Albert Morangki, 2012) menjelaskan tentang kewenangan Pemerintah Daerah dalam bidang yang menjadi urusan Pemerintahan Daerah, bahwa Pemerintah Daerah berkewajiban menjalankan apa yang menjadi urusan Pemerintah Daerah yaitu urusan pemerintah wajib pelayanan dasar, urusan pemerintah wajib bukan pelayanan dasar dan urusan pilihan yang menjadi pilihan bagi Pemerintah Daerah untuk menjalankan atau tidak menjalankannya sesuai dengan kerakteristik daerah masing-masing. Kosekuensi dari adanya otonomi daerah adalah adanya pembagian urusan pemerintahan antara Pemerintah Pusat dengan daerah otonom.

Agar terjalinnya hubungan yang harmonis antara Pemerintah Pusat dan Pemerintah Daerah dalam melaksanakan kewenang, antara Pemerintah Pusat dan Pemerintah Daerah harus terjalin hubungan komunikasi yang baik antara Pemerintah Pusat dan Pemerintah Daerah. Dalam studi (Ulber Silalahi, 2004) tentang komunikasi pemerintahan bahwa komunikasi merupakan dimensi sangat penting bagi organisasi pemerintahan. Komunikasi pemerintahan arus utama untuk membuat suatu kebijakan agar berjalan lancar dan sebagai arus informasi publik. Kemudian penelitian (Septi Nur Wijayanti, 2016) menjelaskan bagaimana pola hubungan antara Pemerintah Pusat dan Pemerintah Daerah, yaitu adanya kontrol Pemerintah Pusat dengan adanya penyerahan urusan melalui penyusunan norma, standar prosedur dan kriteria yang disusun oleh Pemerintah Pusat sebagai landasan bagi Pemerintah Daerah melaksanakan urusan yang diberikan oleh Pemerintah Pusat kepada Pemerintah Daerah, adanya pembinaan dan pengawasan terhadap penyelenggaraan urusan pemerintahan antara Kementerian dengan Pemerintahan Daerah dan Presiden. Hubungan pola tersebut dapat berjalan lancar dengan adanya komunikasi yang baik antara Pemerintah Pusat dan Pemerintah Daerah.

Coronavirus disease 2019 atau yang disebut dengan Covid-19 merupakan penyakit yang diidentifikasikan penyebabnya adalah virus Corona yang menyerang saluran pernapasan. Penyakit ini pertama kali dideteksi kemunculannya di Wuhan, Tiongkok. Sebagaimana diketahui bahwa SARS-Cov-2 bukanlah jenis virus baru 
(Rothan \& Byrareddy, 2020; Huang et al, 2020; Wu et al, 2020). Akan tetapi dalam penjelasan ilmiah suatu virus mampu bermutasi membentuk susunan genetik yang baru, singkatnya virus tersebut tetap satu jenis yang sama dan hanya berganti seragam. Alasan pemberian nama SARS-Cov-2 karena virus corona memiliki hubungan erat secara genetik dengan virus penyebab SARS dan MERS. Menurut NIH (2020) diketahui DNA dari virus SARS-Cov-2 memiliki kemiripan dengan DNA pada kelelawar. Diyakini pula bahwa virus ini muncul dari pasar basah (wet market) di Wuhan, dimana dijual banyak hewan eksotis Asia dari berbagai jenis bahkan untuk menjaga kesegarannya ada yang dipotong langsung di pasar agar dibeli dalam keadaan segar. Kemudian pasar ini dianggap sebagai tempat berkembang biaknya virus akibat dekatnya interaksi hewan dan manusia (D'amore, 2020).

Dalam penangananya, WHO mendeklarasikan pandemic of severe acute respiratory syndrome coronavirus 2 (SARS-CoV-2) menyebabkan kelompok pneumonia fatal akibat penyakit coronavirus 2019 (COVID-19), dengan laporan beberapa pasien yang menerima menggunakan extracorporeal membrane oxygenation (ECMO) (Chen N et al, 2020; Wang D et al, 2020; Yang X et al, 2020; Wu Z \& McGoogan, 2020). Menurut WHO (2020) untuk mengelola pasien yang terduga COVID-19untuk direkomendasikan pemberian ECMO kepada pasien yang memenuhi syarat dengan respiratory distress syndrome (ARDS) terkait COVID-19 di rumah sakit yang direkomendasi oleh pemerintah. Namun, hal tersebut efektifnya akan dipengaruhi oleh pengalaman awal dan kesiapan sistem perawatan kesehatan (MacLaren, et al, 2020). Penanganan tersebut menjadi salah satu dari standar oprasional didalam penanganan COVID-19.

Penyebaran virus corona atau yang disebut (COVID'19) mengakibatkan terjadinya masalah yang serius diseluruh dunia termasuk Indonesia, mulai dari ancaman serius terhadap masalah kesehatan masyarakat yang menyebabkan kematian, masalah sosial yang mengakibatkan terjadinya pembatasan hubungan jarak dilingkungan masyarakat sampai kepada masalah perekonomian yang mengganggu perekonomian secara nasional bahkan internasional. Berdasarkan penelitian (Yuliana, 2020) menjelaskan bahwa Covid-19 adalah virus yang mengakibatkan infeksi saluran pernapasan yang dimulai dengan gejala umum yaitu demam, batuk, dan sulit bernafas hingga mengakibatkan kematian. Penyebaran virus ini diperkirakan hasil dari transmisi hewan ke-manusia, kemudian penyebaran melalui manusia ke-manusia yang melakukan kontak secara langsung. Berdasarkan media (Redaksi CNBC Indonesia, 2020) WHO menjelaskan virus corona adalah penyakit yang disebabkan oleh hewan atau manusia, dimana pada manusia corona dapat dilihat melalui infeksi pernafasan mulai dari flu hingga demam parah. Covid-19 dominan menyerang orang yang lanjut usia, lemah secara fisik ,memiliki riwayat penyakit yang serius, dan orang yang kontak langsung dengan orang yang berasal dari daerah yang terkena wabah covid-19.

Covid-19 merupakan ancaman serius bagi kehidupan masyarakat baik itu kesehatan, sosial, ekonomi dan lainnya. Sehingga pemerintah wajib mengambil tindakan untuk mencegah penyebaran covid-19, salah satu kewajiban Pemerintah adalah 
sebagaimana yang disebutkan dalam Peraturan Perundang-Undangan yaitu kewajiban Pemerintah Pusat dalam menjaga pertahanan dan keamanan Negara, serta kewajiban pemerintah menjamin kesehatan, jaringan sosial dan ekonomi. Salah satu bentuk dari tindakan pemerintah untuk mencegah penyebaran covid-19 adalah pelaksanaan lockdown, dimana kebijakan lockdown diambil alih oleh Pemerintah Pusat sebagai kebijakan Pemerintah Pusat, akan tetapi terjadi local lockdown dibeberapa daerah yang disebabkan oleh penyebaran covid-19 yang semakin meningkat dan mengancam kehidupan masyarakat di beberapa daerah. Dalam pelaksanaan local lockdown tersebut harus terjalin hubungan komunikasi yang baik antara Pemerintah Pusat dan Pemerintah Daerah dalam mencegah penyebaran covid-19 ditingkat lokal. (Sedarmayanti, 2018) menjelaskan setidaknya ada beberapa unsur dalam komunikasi pemerintahan antaranya adalah; Komunikator, Pesan, Media, Komunikan dan Feedback. Berdasarkan latar belakang diatas adapun rumusan masalah yang akan penulis angkat adalah bagaimana pola komunikasi pemerintah pusat dan pemerintaha daerah: kasus dinamika pelaksanaan local lockdown dalam mencegah penyebaran covid'19?, tujuan dari penulisan artikel ini adalah untuk mengetahui komunikasi pemerintah pusat dan pemerintaha daerah: kasus dinamika pelaksanaan local lockdown dalam mencegah penyebaran covid' 19 .

Tidak ada yang berharap bahwa 2020 menjadi salah satu tahun paling sulit bagi Indonesia karena berbagai jenis bencana terjadi. Banjir hebat di ibu kota dan sekitarnya telah menyebabkan penderitaan ekologis. Otoritas lokal menyebutkan bahwa peristiwa tahunan bencana ini menelan biaya potensi ekonomi 960 miliar rupiah hanya sekitar Januari ini (BI, 2020). Namun, jumlahnya dikerdilkan oleh kerusakan yang disebabkan oleh wabah penyakit pernapasan menular berskala global yang muncul dengan kode Covid-19. Menyusul pengumuman yang dibuat oleh Presiden Joko Widodo pada 2 Maret tentang kasus positif pertama Indonesia, negara tersebut masuk ke dalam daftar negara-negara yang terkena dampak pandemi, yang awalnya diidentifikasi di Wuhan, Cina. Kementerian Pariwisata telah menghitung bahwa Indonesia kehilangan potensi ekonomi senilai US \$2,8 miliar hanya dari wisatawan Tiongkok (The Jakarta Post, 2020). Kementerian Koordinator Bidang Kelautan juga mengumumkan putaran kerugian senilai sekitar 500 juta dolar AS yang berasal dari keterlambatan investasi Cina di negara (CNN Indonesia, 2020). Beban ini menyakitkan secara ekonomi karena Indonesia baru-baru ini berupaya untuk menetralisir dampak perang dagang AS-Cina tahun lalu. Selain itu, COVID-19 berdampak pada perekonomian dunia yang semakin meningkat. Sehingga pandemic ini akan membuat perekonomian dunia hilang + US\$ 1 triliun dan pertumbuhan ekonomi dunia di bawah 2\%, jauh di bawah prediksi sebelumnya yang mencapai 2,5\% (World Bank, 2020).

\section{Metode Penelitian}

Metode penelitian yang digunakan adalah pendekatan kualitatif. Dimana penelitian kualitatif adalah penelitian yang menekankan pada kata-kata dan mengumpulkan informasi secara terperinci. Dalam penelitian ini penulis menggunkan 
penilitian kualitatif deskriptif dimana bertujuan menggambarkan sifat-sifat suatu individu, keadaan, gejala, atau kelompok tertentu, penelitian deskriptif dapat dilakukan di laboratorium/pustaka atau dilapangan. Jenis penelitian ini adalah studi literature dimana sumber data diperoleh dari produk hukum, artikel jurnal, dokumen terkait dan sumber media massa.

Kajian literatur sistematis ini awalnya digunakan untuk mengkaji kebijakan di bidang kesehatan di era tahun 80 dan 90an, dengan menganalisis temuan-temuan empiris sebelum membuat sebuah kebijakan (Ridley, 2012:189). Prosedur kajian literatur sistematis, secara umum, adalah sebagai berikut: (1) Penelusuran literatur dilakukan secara jelas dan transparan; (2) Kriteria pemilihan literatur bisa diawali dengan pembacaan terhadap judul, abstrak, lalu kemudian; (3) Pembacaan literatur secara menyeluruh (seluruh kegiatan ini harus tercatat); (4) Peneliti memberikan penilaian baik atau buruk, relevan atau tidak relevannya literatur terhadap tujuan dari kajian literatur yang dilakukan; (5) Prosedur ekstraksi data berdasarkan kriteria yang telah ditetapkan dari hasil penelusuran; (6) Prosedur sintesis dan analisis data dengan metode koding dan/atau klaster; dan (7) Proses interpretasi data dan kesimpulan.

\section{Hasil Dan Pembahasan}

\section{Komunikasi Pemerintah Pusat Dan Pemerintaha Daerah: Kasus Dinamika Pelaksanaan Local Lockdown Dalam Mencegah Penyebaran Covid'19:}

Pada dasarnya prinsip-prinsip interaksi antara pemerintah pusat maupun pemerintah daerah memiliki tanggung jawab dalam melaksanakan roda pemerintahan sesuai dengan kapasitasnya masing-masing. Adapun prinsip-prinsip ini meliputi dari prinsip subtantif yang lebih menekankan kepada penugasan tanggung jawab yang berfokus pada pengelolaan pemerintahan sendiri, mengurus atas legalitas dalam pelaksanaan kebijakan, hal ini menjadi menjelaskna bahwasanya baik pemerintah pusat maupun pemerintah daerah harus mempunyai komunikasi yang baik dalam menangani sebuah permasalahan baik dalam kondisi tidak kondusif.

Selanjutnya prinsip kedua lebih menekankan kepada prinsip instrumental yang memfokuskan dalam relasi hubungan antara pemerintah daearah dan pemerintah pusat dengan memiliki etika publik yang baik seperti kerjasama, saling menukarkan informasi, memiliki kajian sesuai aturan terhadap masing-masing pemerintah dalam menetapkan kondisi keputusan di lingkungannya masing-masing. Hal ini sangat penting karena berkenaan dalam pengaturan kerjasama antara pemerintah daerah dan pemerintah pusat sehingga terhindar klaim-klaim tumpang tindih kebijakan yang dilaksanakan.

Dalam penaggulangan wabah COVID-19 di indonesia seharusnya melakukan komunikasi sehingga tidak ada kesenjangan publik dimana masyarakat bisa memberikan penilaian terhadap setiap pernyataan-pernyataan baik pemerintah pusat maupun pemerinta daerah ketika akan memberikan informasi kepada masyarakat. Pemerintah pusat harus memberi contoh yang baik kepada pemerintah daerah dengan cara memberikan hak dan wewenang sepenuhya dalam penanganan COVID-19, 
sebgaiamana diketahui bahwasanya letak geografis memiliki karakteristik yang pemerintah pusat tidak memahaminya, pemerintah pusat seharusnya membentuk badan pengawas daaerah penanggangan COVID-19 dalam hal yang ke subtantif seperti yang dilakukan beberapa daerah dalam melakukan karantina wilayah, kemudian pemerintah daerah menjalin komunikasi yang baik dengan memberikan report terhadap situasi dan kondisi dengan memegang prinsip subtantif antara pemerintah daerah dan pemerintah pusat.

Kemudian prinsip intrumental dalam penanggangan COVID-19 anatara pemerintah pusat dan pemerintah daerah melakukan kajian yang srategis dalam penanggangan COVID-19, selanjutnya kajian terhadap faktor yang mempengaruhi di beberapa wilayah indonesia penanggangan COVID-19 serta memperhatikan klaim-klaim terhadap penanggangan COVID-19 antara pemerintah pusat dan pemerintah daerah sehingga data yang diterima oleh publik sesuai yang diharapkan karena mempunyai visi misi dan sama, sehingga intrumental dalam pelaksanaannya berjalan dengan baik sesuai dengan manajemen bencana penanggangan COVID-19 yang telah sukses dilakukan beberapa negara laian seperti singapura, china, korea selatan. Prinsip intrumental merupakan alat pemerintah daerah dan pemerintah pusat dalam menentukan kebijakan yang akan dilaksanakan.

\section{Komunikasi Pemerintah Pusat dan Pemerintah Daerah Dalam Penerapan Lockdown}

Pemerintahan mempunyai tugas dan kewajiban untuk melindungi dan menjamin kesehatan, jaringan sosial dan ekonomi masyarakat. Pemerintah Pusat memiliki tugas untuk menjamin pertahanan dan keamanan Negara, sedangkan Pemerintah daerah memiliki kewajiban untuk menjamin kesehatan, pendidikan, sosial pada tingkat lokal.

\section{Bagan 1. Pola Komunikasi Pemerintahan Pusat dan Pemerintahan Daerah}



Sumber: Olahan Penulis (2020) 


\section{a. Komunkator}

\section{Gambar 1.}

\section{Presiden Republik Indonesia Menyampaikan Pesan Terkait Lockdown}

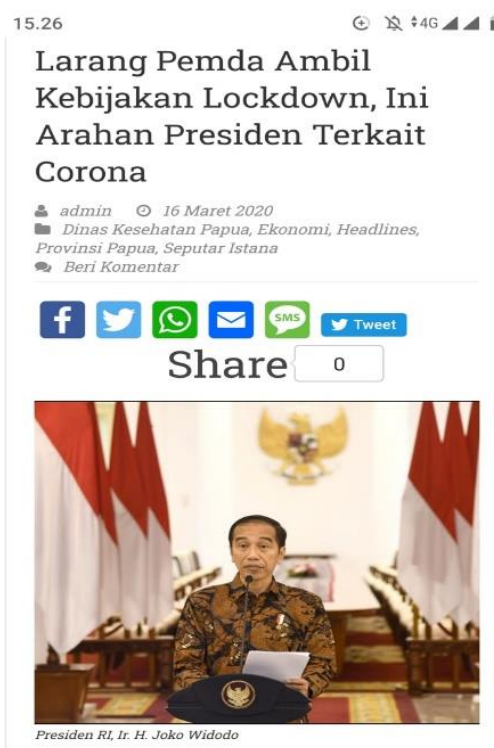

Sumber: Media Papua, 2020

Berdasarkan gambar 1. Diatas menjelaskan bahwa Presiden menjadi komunikator dalam menyampaikan pesan mengenai kebijakan lockdown. Dikutip dari media massa (Mochamad Januar Rizki, 2020), menjelaskan bahwa Pemerintah Pusat melalui Presiden Republik Indonesia menjelaskan bahwa kebijakan penutupan daerah atau yang disebut lockdown adalah kebijakan Pemerintah Pusat. Dalam hal ini Presiden Joko Widodo menjelaskan bahwa Pemerintah Daerah tidak dibenarkan untuk mengambil kebijakan lockdown.

Dalam media online lainnya (Ufi, 2020) menjelaskan bahwa Presiden Republik Indonesia menjelaskan bahwa lockdown adalah kebijakan yang hanya boleh diambil alih oleh Pemerintah Pusat, Pemerintah Daerah tidak dibenarkan untuk menerapkan lockdown pada tingkat daerah. Pemerintah Pusat meminta agar semua kebijakan yang menyangkut kebijakan covid-19 dapat dikoordinasikan kepada Pemerintah Pusat.

\section{b. Media}

Media komunikasi pemerintah salah satunya adalah melalui rapat kabinet, rapat koordinasi dan keterangan pers. Media adalah tempat saluran pesan yang menghantarkan pesan dari komunikator ke komunikan. Dalam penerapan kebijakan lockdown yang menjadi media adalah media sosial dan media massa, kedua media tersebut adalah lembaga independen. Sedangkan media dari pihak Pemerintahan melalui rapat press dan rapat kabinet. Dikutip dari media massa (Insanuddin, 2020) bahwa Presiden Republik Indonesia menyampaikan pesan kepada Kepala Daerah yaitu Gubernur melalui rapat dengan seluruh Gubernur seluruh Indonesia tentang pengambilan kebijakan lockdown yang hanya boleh diambil oleh Pemerintah Pusat. 
Kemjudian dalam kutipan lain (Andhika Prasetia, 2020) menejalskan bahwa Presiden Republik Indonesia mengadakan rapat terbatas dengan 34 Gubernur dalam rapat tersebut Presiden memberikan arahan tentang penanganan covid-19, bahwa Pemerintah Pusat tidak dibenarkan mengambil langkah lockdown.

\section{Gambar 2.}

\section{Presiden Menyampaikan kebijakan Lockdown Kepada Pemerintah Daerah} Melalui Rapat
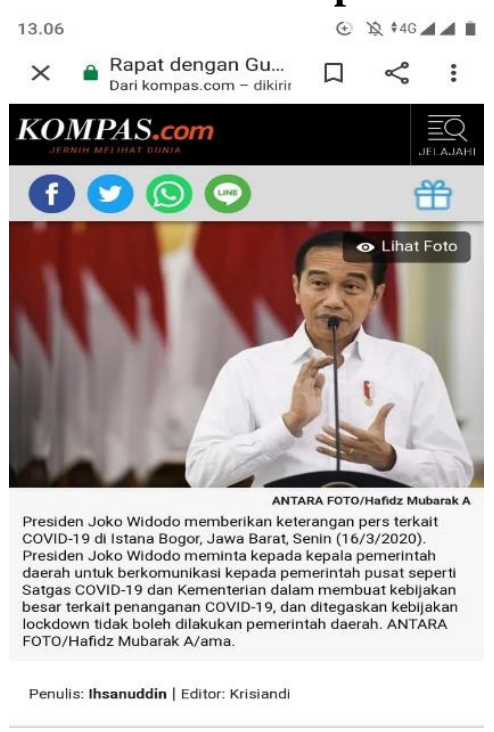

Sumber: Kompas.com,2020

\section{c. Pesan}

\section{Gambar 3. Pesan Presiden Mengenai Lockdown}



Sumber: hukumonline, 2020 
Berdasarkan gambar 3. Diatas adalah bentuk pesan dari kebijakan lockdown yang disampaikan oleh Presiden sebagai Kepala Pemerintahan. Adapun pesan yang disampaikan dalam rapat antara Pemerintah Pusat dan Pemerintah Daerah adalah tentang kebijakan lockdown dan kebijakan dalam menghadapi pandemic virus corona atau covid-19. Pesan yang disampaikan oleh pihak Pemerintah Pusat adalah bahwa Pemerintah Daerah tidak dibenarkan dalam mengambil kebijakan lockdown daerah, kebijakan tentang penanganan covid-19 hanya menjadi kewajiban Pemerintah Pusat.

\section{d. Komunikan}

Pemerintah Daerah menjadi komunikan yaitu menerima pesan mengenai kebijakan lockdown yang disampaikan oleh Pemerintah Pusat. Pemerintah Daerah dalam hal ini mejandi penerima pesan dari Pemerintah Pusat dalam menentukan kebijakan pencegahan penyebaran covid-19. Pemerintah Pusat memberikan pesan kepada Gubernur sebagai perwakilan Kelapa Daerah pada tingkat Provinsi, pesan tersebut adalah mengenai lockdown, bahwa lockdown adalah kebijakan dari Pemerintah Pusat.

\section{Gambar 5. Pesan Kebijakan Lockdown di Sampaikan Kepada Pemerintah Daerah}
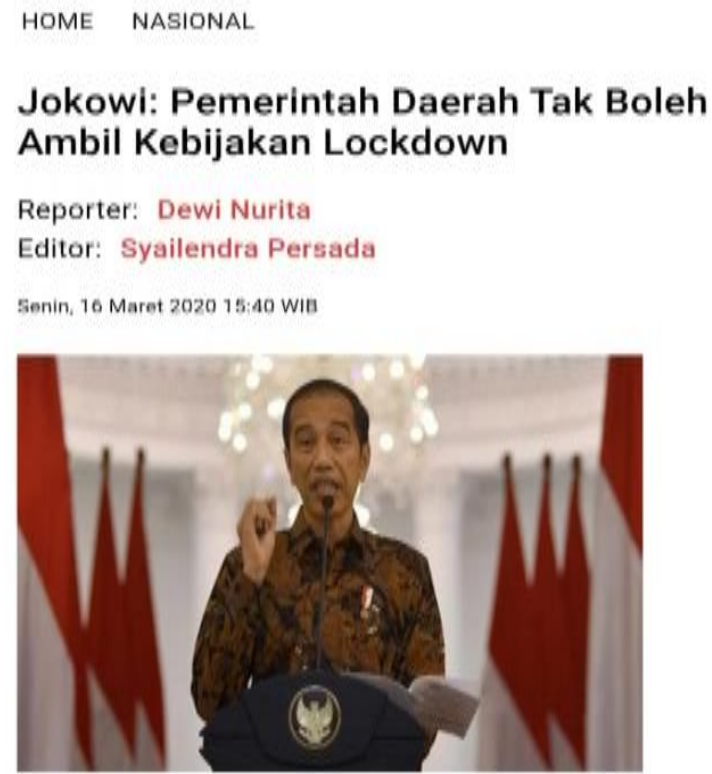

Presiden Joko Widodo (Jokowi) menyampaikan keterangan pers terkait penangangan virus Corona di Istana Bogor, Jawa Barat, Ahad, 75 Maret 2020. Jokowi meminta agar masyarakat

Sumber : Tempo.com (2020) 


\section{e. Feedback}
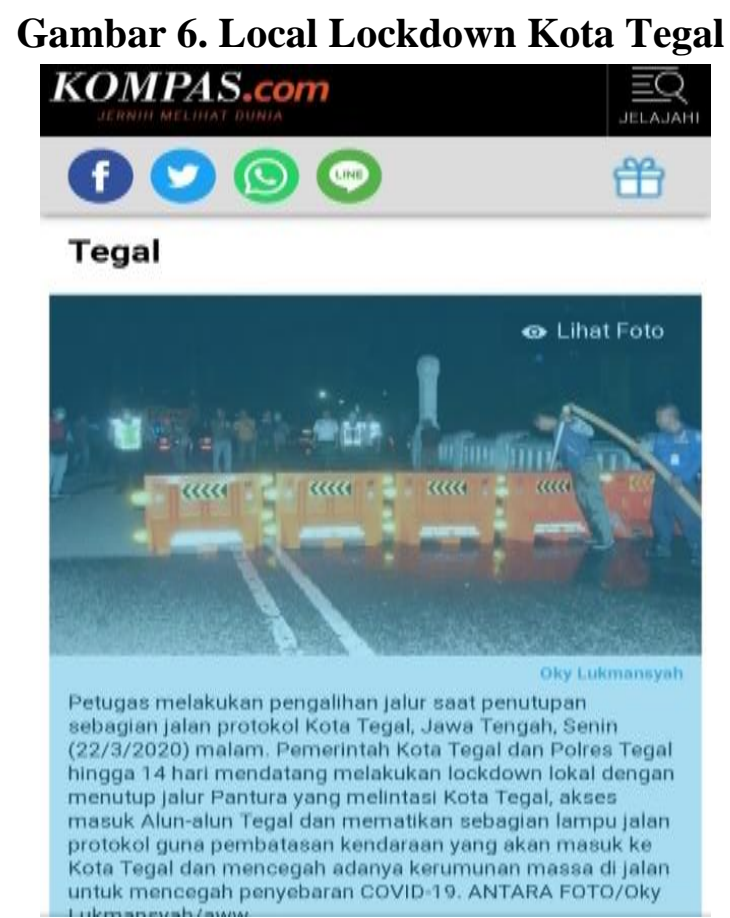

Sumber:Kompas.com,2020

Berdasarkan gambar 1. Merupakan bentuk umpan balik dari kebijakan lockdown yang disampaikan Pemerintah Pusat kepada Pemerintah Daerah bahwa lockdown hanya menjadi kebijakan Pemerintah Pusat, ternyata tanggapan dari Pemerintah Daerah mengenai kebijakan lockdown adanya pro dan kontra pada tingkat lokal. Adanya sebagian daerah yang memilih untuk melakukan local lockdown atau penutupan daerah berbasis lokal, dimana kebijakan local lockdown diambil oleh beberapa Pemerintah Daerah karena alasan urgensi yang mendesak, yaitu penyebaran covid-19 yang semakin meluas pada tingkat lokal/daerah sehingga Pemerintah Daerah mengambil kebijakan local lockdown.

\section{Dinamika Pelaksanaan Local Lockdown di Beberapa Daerah}

\begin{tabular}{|c|c|c|}
\hline No. & Daerah & $\begin{array}{c}\text { Jumlah } \\
\text { Kasus }\end{array}$ \\
\hline 01. & Kota Tegal & 31 Orang \\
\hline 02. & Kota Tasikmalaya & 30 Orang \\
\hline 03. & Provinsi Papua & 240 Orang \\
\hline
\end{tabular}

Sumber: Media Komaps.com (2020)

Berdasarkan table 1. Diatas merupakan beberapa daerah yang menerapkan local lockdown yang dilakukan oleh pihak Pemerintah Daerah yaitu Walikota Tegal, 
Walikota Tasikmalaya dan Pemerintah Provinsi Papua. Kebijakan tersebut diambil oleh pihak Pemerintah Daerah bertujuan untuk mencegah penyebran covid-19.

\section{Kota Tegal}

Berdasarkan media massa (Ahmad Naufal, 2020) menjelaskan bahwa kebijakan local lockdown diambil oleh Walikota Tegal menutup akses masuk ke Kota Tegal selama 4 bulan. Walikota Tegal mempersiapkan sumber daya finansial sebesar 2 Miliar sebagai bantuan kepada masyarakat Tegal melalui Dinas Sosial. Tidak hanya itu kebijakan tersebut didukung oleh Aparatur Sipil Negara dan Dewan Perwakilan Rakyat Daerah Kota Tegal.

\section{Kota Tasikmalaya}

Dikutip dari media massa lainnya (TribunManado.co.id, 2020) menjelaskan bahwa Walikota mengambil kebijakan mengenai local lockdown. Walikota menutup akses transportasi yang masuk kedalam Kota Tasikmalaya, dengan membentuk pos keamanan yang terdiri dari gabungan TNI, Polri dan Aparat Pemerintah Daerah Kota Tasikmalaya.

\section{Papua}

Berdasarkan keterangan media Forum Koordinasi Pimpinan Daerah (FoKoPimDa) Provinsi Papua bersama Bupati dan Walikota seluruh Papu, memberlakukan kebijakan local lockdown. Pemerintah Daerah Papua menutup akses masuk ke-Provinsi Papu dalam rangka pencegahan penyebaran covid-19. Beberapa Kepala Daerah yang melakukan local lockdown mendapatkan respon pro dan kontra dalam pelaksanaan local lockdown. Dinamika permasalahan local lockdown salah satunya adalah bahwa Pemerintah Pusat telah memutuskan bahwa lockdown merupakan kebijakan yang menjadi kebijakan Pemerintah Pusat bukan kebijakan Pemerintah Daerah. Adapun perkembangan dari kasus covid-19 semakin meningkat:

Gambar 1. Grafik Peningkatan Kasus Covid-19 di Indonesia Per-Mei,2020.

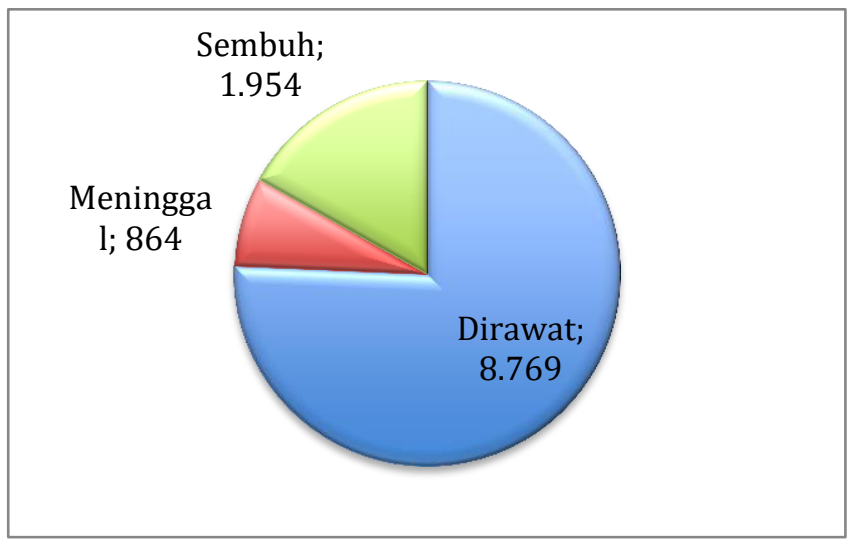

Sumber: Media Kompas,Olahan Penulis (2020) 
Berdasarkan data gambar 1. Grafik diatas menjelaskan jumlah kasus penyebaran covid-19 secara nasional. Berdasarkan data diatas dapai diambil kesimpulan bahwa terdapat kurang lebih 11. 587 kasus covid-19 di Indonesia. Beberapa daerah mengambil kebijakan local lockdown dengan alasan urgensi yang memaksa yaitu ancaman kesehatan masyarakat yang disebabkan oleh serangan covid-19 yang semakin meningkat. Adapun dinamika permasalahan dalam pelaksanaan local lockdown di beberapa daerah adalah sebagai berikut adanya penolakan dari beberapa pihak masyarakat kelas menengah kebawah, atas kekhawatiran perekonomian yang terbatas. Bahwa kebijakan lockdown adalah kebijakan yang menjadi kewajiban Pemerintah Pusat bukan Pemerintah Daerah. Kemudian tingginya tingkat kasus penyebaran covid-19 dikalangan masyarakat lokal yang mengakibatkan Pemerintah Daerah harus mengambil tindakan local lockdown.

\section{Kesimpulan}

Hubungan pemerintah pusat dan pemerintah daerah pada mempunyai prinsip atas kewenangan dan tanggung jawab dalam melaksanakan manajemen bencana COVID 19 harus sesuai dengan aturan regulasi yang ada sesuai dengan prinsip-prinsip interaksi kewenangan daerah baik pusat maupun daerah. hal ini bertujuan untuk menghindari kurangnya koordinasi yang selama ini kurang baik didalam penanganan COVID 19 di Indonesia. Akan tetapi perlu diperhatikan bahwasanya didalam manajemen bencana perlu memperhatikan milestone dari pra COVID hingga menyebar luar ke seluruh indonesia sebagai bentuk evaluasi dalam penanganan bencana terhadap virus menular ini.

Adapun kesimpulan dari penulisan artikel ini adalah sebagai berikut bahwa komunikasi Pemerintah Pusat dan Pemerintah Daerah tidak berjalan secara harmonis, ditandai dengan adanya beberapa daerah yang menerapkan local lockdown diantaranya adalah Kota Tegal, Kota Tasikmalaya dan Provinsi Papua. Tingginya tingkat penyebaran covid-19 menyebabkan Pemerintah Daerah mengambil tindakan tentang kebijakan penangan covid-19 dengan menerapkan local lockdown yaitu penutupan daerah bersekala lokal. Sehingga terjadi pro dan kontra terhadap tindakan Pemerintah Daerah yaitu adanya penolakan dari masyarakat dan kelompok lainnya.

\section{Daftar Pustaka}

Abdul Rauf Alauddin Said. (2015). Pembagian Kewenangan Pemerintah PusatPemerintah Daerah Dalam Otonomi Seluas-Luasnya Menurut UUD 1945. Jurnal Ilmu Hukum, 9(4), 577-602.

Adnan Shereen, M., Khan, S., Kazmi, A., Bashir, N., \& Siddique, R. 2020. COVID-19 infection: origin, transmission, and characteristics of human coronaviruses. Journal of Advanced Research. 
Ahmad Naufal. (2020). Daftar Wilayah di Indonesia yang Terapkan "Local Lockdown." Kompas.Com. Akses 5 Mei 2020. https://www.kompas.com/read/daftarwilayah-di-indonesia-yang-terapkan-local-lockdown-

Albert Morangki. (2012). Tinjauan Terhadap Kewenangan Pemerintah Daerah Dalam Penyelenggaraan Urusan Bidang Pertanahan. Jurnal Unsrat, XX(3), 61-78.

Andhika Prasetia. (2020). Di Depan Gubernur Se-RI Jokowi Tegaskan Tak Lockdown terkait Corona. Detiknews.Com. Akses 5 Mei 2020. https://m.detik.com/news/berita/di-depan-gubernur-se-ri-jokowi-tegaskan-taklockdown-terkait-corona

Aria, Pingit. 2020. Ekonomi Indonesia dalam Skenario Terburuk Akibat Virus Corona. Diakses pada pukul 22.00 WIB WIB tanggal 28 Maret 2020 melalui https://katadata.co.id/telaah/-2020/03/26/ekonomi-indonesia-dalam-skenarioterburuk-akibat-virus-corona

Ariawan, I., P. Riono, M. Farid, and H. Jusril. 2020. "COVID-19 Modelling Scenarios Indonesia," Presentation slides.

Balqis. 2015. Kesenjangan Kesehatan di Daerah Tertinggal. Diakses pada pukul 8.50 WIB WIB tanggal 29 Maret 2020 melalui https://makassar.tribunnews.com/2015/11/12/kesenjangan-kesehatan-di-daerahtertinggal

BI (Bank Indonesia). 2020. BI: Kerugian Banjir Jakarta 2020 Lebih Kecil dibandingkan Tahun-Tahun Sebelumnya," https://www.beritasatu.com/megapolitan/604011/bi-kerugian-banjir-jakarta2020-lebih-kecil-dibanding-tahuntahun-sebelumnya

Chen N, Zhou M, Dong X, et al. 2020. Epidemiological and clinicalcharacteristics of 99 cases of 2019 novel coronavirus pneumonia in Wuhan, China: a descriptive study. Vol. 395, Hal. 507-13.

Chughtai, Abrar A. Seale, H., Islam, Md s., \& Owais, M. 2020. Policies on the use of respiratory protection for hospital health workers to protect from coronavirus disease (COVID-19). International Journal of Nursing Studies. Vol. 105

CNN Indonesia. 2020. "Luhut Sebut Potensi Rugi Investasi US\$500 Juta Karena Corona,". https://www.cnnindonesia.com/ekonomi/20200220201307-92476597/luhut-sebut-potensi-rugi-investasi-us-500-juta-karena-corona

D'amore, Rachael. 2020. Coronavirus: Where did it come from and how did we get here?, Diakses pada pukul 15.20 WIB tanggal 29 Maret 2020 melalui https://globalnews.ca/news/-6682629/coronavirus-how-did-it-start

Deng, Sheng-Qun \& Peng, Hong-Juan. 2020. Characternses to the Coronavirus Disease 2019 Outbreak in China. Journal of Clinical Medicine. Vol. 9, No. 575.

Epidemiology Working Group. 2020. The epidemiological characteristics of an outbreak of 2019 novel coroavirus diseases (COVID-19) in China. Chin J Epidemiol. Vol. 2, hal. 145-151.

Evans, D. and E. Werker (2020): "What a Populations Age Structure Means for COVID-19s Impact in Low-Income Countries," https:/www.cgdev.org/blog/ 
what-populations-age-structure-means-COVID-19s-impact-low-incomecountries

Heldavidson. 2020. First Covid-19 case happened in November, China government records show report, Diakses pada pukul 9.30 WIB WIB tanggal 29 Maret 2020 melalui https://www.theguardian.com/world/2020/mar/13/first-covid-19-casehappened-in-november-china-government-records-show-report

Insanuddin. (2020). Rapat dengan Gubernur, Jokowi Ungkap Alasan Larang Lockdown. Kompas.Com. Akses 5 Mei 2020. https://amp-kompas-com/nasional/read/rapatdengan-gubernur-jokowi-ungkap-alasan-larang-lockdown

Mochamad Januar Rizki. (2020). Jokowi: Lock Down adalah Kebijakan Pemerintah Pusat. M.Hukumonline.Com. Akses $\quad 5 \quad$ Mei 2020.https://m.hukumonline.com/berita/baca/jokowi-lock-down-adalahkebijakan-pemerintah-pusat

Redaksi CNBC Indonesia. (2020). Simak Penjelasan WHO Soal Apa itu Corona dan Cirinya. Www.Cnbcindonesia.Com. Akses 5 Mei 2020 https://www.cnbcindonesia.com/simak-penjelasan-who-soal-apa-itu-corona-dancirinya

Sedarmayanti. (2018). Komunikasi Pemerintahan. PT Refika Aditama.

Septi Nur Wijayanti. (2016). Hubungan Antara Pusat dan Daerah Dalam Negara Kesatuan Republik Indonesia Berdasarkan Undang-Undang Nomor 23 Tahun 2014. Jurnal Media Hukum, 23(2), 186-199.

Setiawan, R., \& Mahadiansar, M. (2020). Forecasting analysis: The Riau Islands local government role In Covid-19 disaster management. Jurnal Studi Pemerintahan, 11(3), 401-426.

TribunManado.co.id. (2020). Tempat di Indonesia Yang Sudah Menerapkan Local Lockdown, Akses Masuk Daerah Ditutup. Tribunnews. Akses Mei 5 Mei. https://manad0.tribunnews.com/tempat-di-indonesia-yang-sudah-menerapkanlocal-lockdown-akses-masuk-daerah-ditutup

Ufi. (2020). Lockdown adalah Kebijakan Pemerintah Pusat. Lenteratoday.Com. Akses 5 Mei 2020. https://lenteratoday.com/lockdown-adalah-kebijakan-pemerintahpusat

Ulber Silalahi. (2004). Komunikasi Pemerintahan: Mengirim Dan Menerima Informasi Tugas Dan Informasi Publik. Jurnal Administrasi Publik, 3(1), 36-54.

Wirazilmustan, Rahmat, A. (2018). Konsep Hubungan Kewenangan Antara Pemerintah Pusat Dan Pemerintah Daerah Dalam Bingkai Negara Kesatuan Dengan Corak Otonomi Luas. Jurna; Hukum Progresif, XII(2), 2131-2145.

Yuliana. (2020). Corona Virus Diseases (COVID-19) sebuah tinjaun literatur. Jurnal Wellnes and Healthy Magazine, 2(1), 187-192. 